\title{
New Trypetheliaceae from the Amazon basin in Rondônia (Brazil), the centre of diversity of the genus Astrothelium
}

\author{
André APTROOT and Marcela Eugenia da Silva CÁCERES
}

\begin{abstract}
The following 24 new species of Trypetheliaceae are described after three weeks of fieldwork in an area with a radius of $50 \mathrm{~km}$ around Porto Velho in Rondonia: Astrothelium bivelum with astrothelioid ascomata, 5-septate ascospores with polar gelatinous caps, and a thallus without lichexanthone; A. curvisporum with bent, 5-septate ascospores of $115-135 \times 29-36 \mu \mathrm{m}$ with a $17-22 \mu \mathrm{m}$ thick gelatinous layer; $A$. decemseptatum with pseudostroma that are essentially black and look like breaking through the bark, with anthraquinones mostly on the pseudostromata but also on some parts of the thallus, best seen under UV light as the colour of the pruina is not very strong, and ascospores (7-)9-11-septate, fusiform, 50-65 $\times 11-17 \mu \mathrm{m} ; A$. disjunctum with black pseudostroma and ascospores 3-septate, (27-)29-33 $\times(8-)$ 12-14 $\mu \mathrm{m} ; A$. duplicatum which is similar to $A$. mesoduplex, but pseudostroma are only yellowish inside and ascospores 45-55 $\times 11-15 \mu \mathrm{m} ; A$. eumultiseptatum which is similar to $A$. eustomum, but with 9-11-septate ascospores of $65-70 \times 15-17 \mu \mathrm{m} ; A$. eustomurale which is also similar to $A$. eustomum, but with submuriform ascospores of $37-45 \times 15-19 \mu \mathrm{m} ; A$. flavoduplex which is similar to $A$. mesoduplex, but with ascospores 110-350 $\times 20-27 \mu \mathrm{m}$ and the thallus containing lichexanthone; $A$. flavomurisporum with deeply immersed ascomata with muriform ascospores of $165-200 \times 28-35 \mu \mathrm{m}$, with a distinctly thickened central septum and yellow oil; $A$. flavostromatum which is close to $A$. aeneoides and mainly differs by the bullate thallus and the cream pseudostromata; $A$. flavum which is similar to $A$. aeneum, but differs in the contrast between the linear to reticulate yellow stromata and the unpigmented thallus, and the ascospores of 16-18 × 6-7 $\mu \mathrm{m} ; A$. mesoduplex which is similar to A. flavoduplex, but with ascospores $90-100 \times 20-23 \mu \mathrm{m}$ and a thallus without lichexanthone; $A$. nigrum with mostly conical black pseudostromata that contrast sharply with the thallus, superficially resembling Pyrenula infraleucotrypa; $A$. novemseptatum which is similar to $A$. eumultiseptatum, but without lichexanthone anywhere in the thallus or pseudostroma; $A$. ochroleucoides which is similar to $A$. corallinum, but with lichexanthone on the thallus and pseudostromata; A. octoseptatum which is similar to $A$. eumultiseptatum, but with the whole pseudostroma, not just the ostioles, containing lichexanthone, and ascospores somewhat asymmetrical, which is highlighted by the unusual dominant even number of septa (eight) and the asymmetrically placed central septum in the case of uneven septum numbers; $A$. quatuorseptatum which is similar to $A$. octoseptatum Aptroot \& M. Cáceres, but without lichexanthone, ascospores somewhat asymmetrical, which is highlighted by the unusual dominant even number of septa (four) and the asymmetrically placed central septum in the case of uneven septum numbers; $A$. robustosporum with solitary ascomata with an eccentric ostiole, and ascospores 11-15-septate, 90-125 × 20-27 $\mu \mathrm{m} ;$ A. solitarium which is similar to $A$. ceratinum (Fée) Aptroot \& Lücking, but with ascospores $33-36 \times 10-11 \mu \mathrm{m} ; A$. stromatofluorescens which is close to $A$. phlyctaena, but with lichexanthone only on the pseudostroma, not on the thallus; $A$. supraclandestinum is close to A. subclandestinum, but the hamathecium is not inspersed; $A$. testudineum with solitary ascomata with an eccentric ostiole, an inspersed hamathecium, and ascospores 8 per ascus, muriform, $50-65 \times 23-27 \mu \mathrm{m}$; $A$. xanthosuperbum which is similar to $A$. disjunctum, but with muriform ascospores, $130-160 \times 28-35 \mu \mathrm{m}$; and Pseudopyrenula flavoreagens which is similar to P. subgregaria, but with lichexanthone in the thallus. Only a few species were also found elsewhere, such as other areas of Brazil, or in Venezuela, Colombia, Guyana, Panama, Australia and/or Papua New Guinea. Currently, 55 species of Trypetheliaceae are known from this spot, including 46 species of Astrothelium. The Amazon basin is the centre of diversity for the family, at least for Astrothelium, the largest genus in the family.
\end{abstract}

Key words: Australia, Colombia, Guyana, lichens, Panama, Papua New Guinea, Pseudopyrenula, Venezuela

A. Aptroot: ABL Herbarium, G.v.d.Veenstraat 107, NL-3762 XK Soest, The Netherlands. Email: andreaptroot@gmail.com
M. E. da S. Cáceres: Departamento de Biociências, Universidade Federal de Sergipe, CEP: 49500-000, Itabaiana, Sergipe, Brazil. 


\section{Introduction}

The family Trypetheliaceae is most abundant and also generally thought to be species-rich in open forests such as Caatinga vegetation. However, recent collections from expeditions in Venezuela, Guyana, Bolivia and Brazil (especially Rondônia) suggest that it may be most speciose in rainforest, where it grows both on tree trunks and branches. Recently, numerous undescribed species of this family have been found in these countries.

The rainforest in Rondônia is special in that it has a relatively open structure, but contains many large trees. In response, lichens cover most of the bark from the top of the trees to the forest floor, compared with other rainforests where lichens are largely replaced by bryophytes at ground level. The reason is most probably that the soil is extremely nutrientpoor. Until the start of the current research project in 2012, only about twelve lichens had been reported, mostly foliicolous species (Lücking 2008). However, the first results of this survey for lichens in this largely primary forest shows that the region has among the highest epiphytic lichen diversity in the world. There are many so far undescribed species and genera in groups such as Graphidaceae (Cáceres et al. 2014b), Arthoniales (Cáceres et al. 2014c) and the pyrenocarps (Aptroot \& Cáceres 2013). Surprisingly, there are undescribed species, or some described recently, that are locally abundant e.g. Pyrenula spp. (Aptroot et al. 2013b).

The high lichen biodiversity is somewhat surprising in the light of the palynological record, which shows that the rainforest in Rondônia at the southern edge of the Amazonian basin is of a geologically recent age and was replaced by savannah in drier or colder periods in the Tertiary and Quaternary, including the ice ages (Hooghiemstra \& van der Hammen 1998; Colinvaux et al. 2000). The explanation may be that lichens are better dispersers than most other organisms, on which the rapid changes in vegetation may have had a greater effect.

We sampled extensively for Trypetheliaceae in Rondônia and made a distinction between primary and secondary forest, and between species growing on trunks and branches in the primary forest. The primary forest is the most speciose. Quite unexpectedly, the species on the branches are exclusive to that habitat and do not occur on trunks in the same forest or in nearby secondary localities. Below we describe 25 new species of Trypetheliaceae found during three weeks of fieldwork in a radius of $50 \mathrm{~km}$ from Porto Velho in Rondônia. From the same fieldwork area, 27 previously described species of Trypetheliaceae were reported by Aptroot et al. (2013a) and Cáceres et al. (2014a), to which three species should be added that were at that time not yet taken from synonymy with others, but were already recognized in the material.

The generic concept applied here follows the phylogenetic studies by Nelsen et al. (2014). All species are keyed out in Aptroot \& Lücking (2016).

\section{Material and Methods}

Identification and descriptive work was carried out in Itabaiana, Universidade Federal de Sergipe, using a Leica EZ4 stereomicroscope and a Leica DM500 compound microscope, and also in Soest using an Olympus SZX7 stereomicroscope and an Olympus BX50 compound microscope with interference contrast, connected to a Nikon Coolpix digital camera. Sections were mounted in tap water, in which all measurements were also taken. The chemistry of all specimens was investigated under UV light, and usually spot tests with $10 \%$ $\mathrm{KOH}$ were carried out. The chemistry of the type specimens was investigated by thin-layer chromatography (TLC) using solvent A (Orange et al. 2001).

\section{The New Species}

\section{Astrothelium bivelum Aptroot \& M. Cáceres sp. nov.}

\section{MycoBank No.: MB 815159}

Astrothelium with astrothelioid ascomata, 5-septate ascospores with polar gelatinous caps, and thallus without lichexanthone.

Type: Brazil, Rondônia, Porto Velho, Parque Natural Municipal de Porto Velho, $8^{\circ} 41^{\prime} 10^{\prime \prime}$, $63^{\circ} 52^{\prime} 05^{\prime \prime} \mathrm{W}$, alt. c. $100 \mathrm{~m}$, on tree bark in primary rainforest, 19 November 2012, M. E. S. Cáceres E A. Aptroot 15608 (ISE-holotype; $\mathrm{ABL}$ - isotype).

\section{(Figs $1 \mathrm{~A} \& 5 \mathrm{~A})$}

Thallus corticate, smooth, somewhat shiny, continuous, covering areas $\leq 3 \mathrm{~cm}$ diam., 

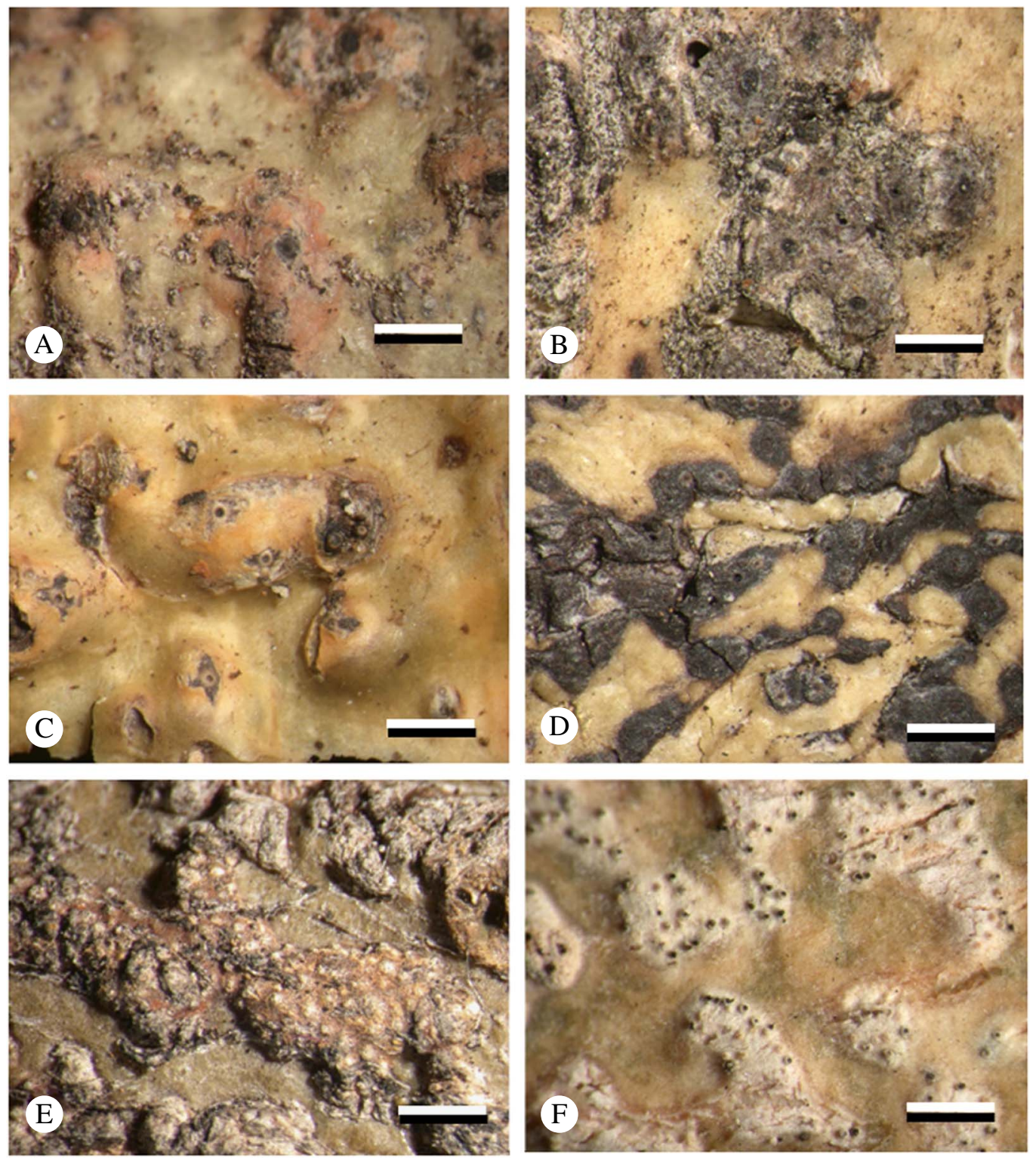

FIg. 1. Habitus of new species of Trypetheliaceae (isotypes). A, Astrothelium bivelum; B, A. curvisporum; $\mathrm{C}, A$. decemseptatum; D, A. disjunctum; E, A. duplicatum; F, A. eumultiseptatum. Scales $=1 \mathrm{~mm}$. In colour online.

c. $0 \cdot 1 \mathrm{~mm}$ thick, ochraceous green, surrounded by an irregular and rough $c .0 .4 \mathrm{~mm}$ wide black prothallus that seems to contain pycnidia, not inducing gall formation of the host bark.

Ascomata pyriform, 0.5-0.7 mm diam., mostly 2-6 aggregated, immersed in pseudostromata with a surface only slightly different from the thallus, but not corticate, and which are distinctly raised above the thallus, irregular in outline, sides sloping, $\leq c .3 \mathrm{~mm}$ diam. and $1 \mathrm{~mm}$ high, ochraceous, not containing bark tissue. Wall carbonized all around, $\leq c .70 \mu \mathrm{m}$ thick. Ostioles eccentric, fused, 
flat, black, surrounded by a black rim. Hamathecium not inspersed with oil globules. Asci with 8 ascospores. Ascospores hyaline, 5-septate, fusiform, 55-65 $\times 18-21 \mu \mathrm{m}$, pointed, lumina diamond-shaped, with two polar gelatinous caps $\leq 6 \mu \mathrm{m}$ thick.

Pycnidia not observed, but prothallus lines seemingly containing old pycnidia.

Chemistry. Thallus surface UV-, thallus medulla $\mathrm{K}-$; pigmented parts of pseudostroma UV+ pink, K-. TLC: besides an unidentified pigment, no secondary substances detected.

Ecology and distribution. On smooth bark of trees in primary forest. Known only from Brazil.

Discussion. This is one of the few astrothelioid species with 5 -septate ascospores but without lichexanthone. The species is characterized by the polar gelatinous caps, a spectacular character known from few lichens. However, it is a character that may disappear in older material, especially when preservation conditions are suboptimal. Material without polar caps is closest to A. supraclandestinum (see below), which differs by the absence of the pinkish pigment.

\section{Astrothelium curvisporum Aptroot \& M. Cáceres sp. nov.}

\section{MycoBank No.: MB 815160}

Astrothelium with curved, 5-septate ascospores of 115$135 \times 29-36 \mu \mathrm{m}$ with a $17-22 \mu \mathrm{m}$ thick gelatinous layer.

Type: Brazil, Rondônia, Porto Velho, Parque Natural Municipal de Porto Velho, 841'10"S, 6352'05"W, alt. c. $100 \mathrm{~m}$, on twig in primary rainforest, 17 November 2012, M. E. S. Cáceres \& A. Aptroot 15556 (ISEholotype; ABL - isotype).

\section{(Figs 1B \& 5B)}

Thallus corticate, smooth, somewhat shiny, continuous, covering areas $\leq 5 \mathrm{~cm}$ diam., c. $0.2 \mathrm{~mm}$ thick, olive-green to olivebrown, medulla whitish, not surrounded by a prothallus, not inducing gall formation of the host bark.

Ascomata globose, $0.8-1.2 \mathrm{~mm}$ diam., immersed in groups of 3-15 in pseudostromata with a surface different from the thallus, and distinctly raised above the thallus, irregular in outline, sides sloping, $\leq c .4 \mathrm{~mm}$ diam. and $1 \mathrm{~mm}$ high, brown with whitish pruina, inside containing bark tissue. Wall dark brown all around, $\leq c .70 \mu \mathrm{m}$ thick. Ostioles apical, not fused, flat, black, often surrounded by a round, flat black disc of c. $0.2 \mathrm{~mm}$ diam. Hamathecium heavily inspersed with hyaline oil globules. Asci with 8 ascospores. Ascospores hyaline, 5-septate, fusiform, distinctly curved, 115-135 $\times$ $29-36 \mu \mathrm{m}$, ends rounded, lumina diamondshaped, surrounded by a gelatinous layer 17-22 $\mu \mathrm{m}$ thick.

Pycnidia not observed.

Chemistry. Thallus surface UV-, thallus medulla $\mathrm{K}-$; pseudostroma surface UV-. TLC: no secondary substances detected.

Ecology and distribution. On twig in primary forest. Known only from Brazil.

Discussion. This species is characterized by the large, curved, 5-septate ascospores and especially by the very thick gelatinous layer, which is the thickest observed in the whole family. However, it is a character that might disappear in older material, especially when preservation conditions are suboptimal. Material without the gelatinous layer is closest to $A$. sipmanii Aptroot, which has straight ascospores.

\section{Astrothelium decemseptatum Aptroot \& M. Cáceres sp. nov.}

\section{MycoBank No.: MB 815161}

Astrothelium with pseudostroma that are essentially black and look like they are breaking through the bark, with anthraquinones, mostly on the pseudostromata but also on some parts of the thallus, best seen under UV light as the colour of the pruina is not very strong; ascospores (7-)9-11-septate, fusiform, 50-65 × 11-17 $\mu \mathrm{m}$.

Type: Brazil, Rondônia, Sítio Ecológico Buriti on Lago Cujubim NE of Porto Velho, 8 ${ }^{\circ} 35^{\prime} 17^{\prime \prime S}$, $63^{\circ} 40^{\prime} 40^{\prime \prime} \mathrm{W}$, alt. c. $100 \mathrm{~m}$, on tree bark in disturbed rainforest, 18 November 2012 , M. E. S. Cáceres $\mathcal{E}$ A. Aptroot 15484 (ISE-holotype; ABL-isotype).

\section{(Figs 1C \& 5C)}

Thallus corticate, smooth, somewhat shiny, continuous, covering areas $\leq 7 \mathrm{~cm}$ diam., under $0.1 \mathrm{~mm}$ thick, pale yellowish grey, not surrounded by a prothallus, not inducing gall formation of the host bark. 
Ascomata pyriform, c. $0.6-1.2 \mathrm{~mm}$ diam., mostly 2-5 aggregated, mostly immersed in the bark tissue, surfacing in a blackish, partly orange pruinose pseudostroma that seems to break through the corticated bark. Wall carbonized, $\leq c .80 \mu \mathrm{m}$ thick. Ostioles eccentric, fused, flat, tiny black dots surrounded by a whitish zone c. $0.1 \mathrm{~mm}$ wide. Hamathecium inspersed with hyaline oil globules. Asci with 8 ascospores. Ascospores hyaline, (7-)9-11septate, fusiform, $50-65 \times 11-17 \mu \mathrm{m}$, ends rounded, lumina diamond-shaped, surrounded by a $2-4 \mu \mathrm{m}$ thick gelatinous layer.

Pycnidia not observed.

Chemistry. Thallus surface partly UV+ pink to orange, partly negative, thallus medulla $\mathrm{K}-$; pseudostroma surface UV+ red, pigmented parts of pseudostroma $\mathrm{K}+$ red. TLC: anthraquinones.

Ecology and distribution. On smooth bark of trees in disturbed forest. Known only from Brazil.

Discussion. This species contains anthraquinones, mostly on the pseudostromata but also on some parts of the thallus. It is best seen under UV light (the colour of the pruina is not very strong). The pseudostroma are essentially black and look like they are breaking through the bark. It is most similar to A. cinereorosellum (Krempelh.) Aptroot \& Lücking, but this has shorter ascospores and contains lichexanthone in the thallus.

Additional specimen seen. Brazil: same as the type, 15488 (ABL, ISE).

\section{Astrothelium disjunctum Aptroot \& M. Cáceres sp. nov.}

MycoBank No.: MB 815162

Astrothelium with black pseudostroma; ascospores 3-septate, (27-)29-33 × (8-)12-14 $\mu \mathrm{m}$.

Type: Brazil, Rondônia, Porto Velho, Parque Natural

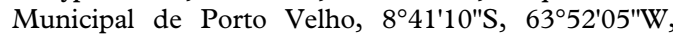
alt. c. $100 \mathrm{~m}$, on tree bark in park near rainforest, 16 November 2012, M. E. S. Cáceres \& A. Aptroot 15161 (ISE-holotype; ABL-isotype).

(Fig. 1D)

Thallus corticate, smooth, somewhat shiny, continuous, covering areas $\leq 5 \mathrm{~cm}$ diam., c. $0.2 \mathrm{~mm}$ thick, pale yellowish grey, surrounded by a black prothallus line c. $0.3 \mathrm{~mm}$ wide, not inducing gall formation of the host bark.

Ascomata globose, $0.4-0.6 \mathrm{~mm}$ diam., immersed in groups of 5-25 in pseudostromata (resembling true stromata) with a black surface different from the thallus, and which are distinctly raised above the thallus and mostly linear in outline and often forming a network. Wall dark brown all around, $\leq c .100 \mu \mathrm{m}$ thick. Ostioles apical, not fused, flat, tiny black dots surrounded by a whitish zone c. $0.1 \mathrm{~mm}$ wide. Hamathecium not inspersed with oil globules. Asci with 8 ascospores. Ascospores hyaline, 3-septate, fusiform, (27-)29-33 × (8-)12-14 $\mu \mathrm{m}$, ends rounded, lumina diamond-shaped, not surrounded by a gelatinous layer.

Pycnidia not observed.

Chemistry. Thallus surface UV-, thallus medulla $\mathrm{K}-$; pseudostroma UV-, K-. TLC: no secondary substances detected.

Ecology and distribution. On smooth bark of trees in park near rainforest. Known only from Brazil.

Discussion. Rather similar to $A$. bicolor (Taylor) Aptroot \& Lücking, but with larger ascospores and a black pseudostroma that somewhat resembles a true fungal stroma.

Additional specimens seen. Brazil: same as the type, 15203, 15221 (ABL, ISE).

\section{Astrothelium duplicatum Aptroot \& M. Cáceres sp. nov.}

\section{MycoBank No.: MB 815163}

Astrothelium similar to $A$. mesoduplex, but pseudostroma only yellowish inside and ascospores $45-55 \times$ $11-15 \mu \mathrm{m}$.

Type: Brazil, Rondônia, Porto Velho, Parque Natural Municipal de Porto Velho, $8^{\circ} 41^{\prime} 10^{\prime \prime} \mathrm{S}, 63^{\circ} 52^{\prime} 05^{\prime \prime} \mathrm{W}$, alt. c. $100 \mathrm{~m}$, on tree bark in park near rainforest, 16 November 2012, M. E. S. Cáceres \& A. Aptroot 15165 (ISE-holotype; ABL-isotype).

\section{(Fig. 1E)}

Thallus corticate, smooth, somewhat shiny, continuous, covering areas $\leq 5 \mathrm{~cm}$ diam., 
c. $0 \cdot 1 \mathrm{~mm}$ thick, olive-green, surrounded by a black prothallus line c. $0.3 \mathrm{~mm}$ wide, not inducing gall formation of the host bark.

Ascomata globose, $0.4-0.6 \mathrm{~mm}$ diam., immersed in groups of c. 5-50 in pseudostromata. Pseudostromata with a surface different from the thallus, c. $0.5-1.0 \mathrm{~mm}$ raised above the thallus, irregular to linear or reticulate in outline, $\leq c .3 \mathrm{~mm}$ wide, pale brown, pale yellow inside. Wall dark brown all around, $\leq$ c. $40 \mu \mathrm{m}$ thick. Ostioles apical, not fused, flat to convex, brown. Hamathecium not inspersed with oil globules. Asci with 8 ascospores. Ascospores hyaline, muriform, fusiform, $45-55 \times 11-15 \mu \mathrm{m}$, ends rounded, lumina angular with many oblique septa, not surrounded by a gelatinous layer.

Pycnidia not observed.

Chemistry. Thallus surface UV-, thallus medulla K-; pseudostroma surface UV+ red, medulla $\mathrm{K}+$ blood red. TLC: an anthraquinone, probably parietin.

Ecology and distribution. On twigs of trees in primary forest and on bark in park near rainforest. Known only from Brazil.

Discussion. This is one of a group of probably related new species that mainly occur on branches in rainforest. The habitus is similar in shape, but not in colour, to several other Astrothelium species. Astrothelium flavoduplex and A. ochroleucoides differ, for example, by the presence of lichexanthone, $A$. mesoduplex and $A$. flavoduplex both by the yellow to orange pseudostromata, and all these three species by the longer ascospores.

Additional material seen. Brazil: same as the type, but on twig in rainforest, 2012, M. E. S. Cáceres $\mathcal{E} A$. Aptroot 11245 (ABL, ISE); ibid., 2012, M. E. S. Cáceres $\mathcal{F}$ A. Aptroot 15566 (ABL, ISE).

\section{Astrothelium eumultiseptatum Aptroot \& M. Cáceres sp. nov.}

MycoBank No.: 815164

Astrothelium similar to Astrothelium eustomum (Mont.) Müll. Arg., but with 9-11-septate ascospores 65-70× $15-17 \mu \mathrm{m}$.

Type: Brazil, Rondônia, Fazenda São Francisco off

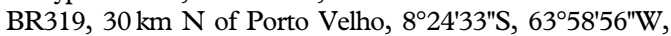
alt. c. $100 \mathrm{~m}$, on tree bark in primary rainforest, 15 March
2012, M. E. S. Cáceres E A. Aptroot 11828 (ISE-holotype; $\mathrm{ABL}$-isotype).

(Figs 1F \& 5D)

Thallus corticate, smooth, somewhat shiny, continuous, covering areas $\leq 7 \mathrm{~cm}$ diam., under $0.1 \mathrm{~mm}$ thick, pale yellowish grey, surrounded by a black prothallus line c. $0.3 \mathrm{~mm}$ wide, not inducing gall formation of the host bark.

Ascomata pyriform, c. $0.6-1.2 \mathrm{~mm}$ diam., mostly 2-5 aggregated, mostly immersed in the bark tissue below pseudostromata with a whitish surface different from the thallus, and which are distinctly raised above the thallus and mostly linear in outline and often forming a network. Wall carbonized, $\leq c .80 \mu \mathrm{m}$ thick. Ostioles eccentric, fused, flat, pale brown, white pruinose, surrounded by a whitish zone. Hamathecium not inspersed with oil globules. Asci with 8 ascospores. Ascospores hyaline, 9-11-septate, fusiform, 65-70 $\times$ 15-17 $\mu \mathrm{m}$, ends pointed, lumina diamondshaped, not surrounded by a gelatinous layer.

Pycnidia abundant, black, only on the pseudostromata.

Chemistry. Thallus surface UV-, thallus medulla $\mathrm{K}-$; ostiolar region $\mathrm{UV}+$ yellow. TLC: lichexanthone.

Ecology and distribution. On smooth bark of trees in primary forest. Known only from Brazil.

Discussion. This species is similar to Astrothelium eustomum (Mont.) Müll. Arg., but differs by the 9-11-septate rather than 3-5septate, and much larger, ascospores. The also newly described $A$. macrostomum Aptroot is intermediate, with 5-7-septate ascospores; the following species has submuriform ascospores.

\section{Astrothelium eustomurale Aptroot \& M. Cáceres sp. nov.}

\section{MycoBank No.: MB 815165}

Astrothelium similar to Astrothelium eustomum (Mont.) Müll. Arg., but with submuriform ascospores $37-45 \times$ $15-19 \mu \mathrm{m}$.

Type: Brazil, Rondônia, Porto Velho, Parque Natural Municipal de Porto Velho, $8^{\circ} 41^{\prime} 10^{\prime \prime}$, 635' $02^{\prime \prime W}$, 
alt. c. $100 \mathrm{~m}$, on tree bark in primary rainforest, 9-12 March 2012, M. E. S. Cáceres E A. Aptroot 11547 (ISE-holotype; ABL-isotype).

\section{(Figs 2A \& 5E)}

Thallus corticate, smooth, somewhat shiny, continuous, covering areas $\leq 12 \mathrm{~cm}$ diam., under $0.1 \mathrm{~mm}$ thick, pale yellowish grey, not surrounded by prothallus, not inducing gall formation of the host bark.

Ascomata pyriform, c. $0 \cdot 6-1.2 \mathrm{~mm}$ diam., mostly 2-5 aggregated, mostly immersed in the bark tissue below pseudostromata with a whitish surface different from the thallus, and which are distinctly raised above the thallus and mostly irregular in outline, not forming a network. Wall carbonized, $\leq c$. $80 \mu \mathrm{m}$ thick. Ostioles eccentric, fused, flat, pale brownish, white pruinose, surrounded by a whitish zone. Hamathecium not inspersed with oil globules. Asci with 8 ascospores. Ascospores hyaline, submuriform, fusiform, 37-45 $\times 15-19 \mu \mathrm{m}$, ends pointed, lumina diamond-shaped, often surrounded by a gelatinous layer $\leq 10 \mu \mathrm{m}$ thick.

Pycnidia abundant, black, only on the pseudostromata.

Chemistry. Thallus surface $\mathrm{UV}-$, thallus medulla $\mathrm{K}-$; ostiolar region $\mathrm{UV}+$ yellow. TLC: lichexanthone.

Ecology and distribution. On smooth bark of trees in primary forest. Known only from Brazil; locally common.

Discussion. This species is similar to Astrothelium eustomum, but differs in the submuriform rather than 3-5-septate ascospores. The also newly described $A$. macrostomum Aptroot with 5-7-septate ascospores, and the preceding species with 9-11-septate ascospores, are intermediate. This new species is locally common.

Additional specimens seen (all ABL, ISE). Brazil: same as the type, 11360, 11361, 11362, 11364, 11402; same locality as the type, 2012, 15615; Fazenda São Francisco off BR319, $30 \mathrm{~km} \mathrm{~N}$ of Porto Velho, alt. c. $100 \mathrm{~m}$, on tree bark in primary rainforest, 2012, Cáceres \& Aptroot 11857, 11940; UNIR Federal University campus SW of city, alt. c. $100 \mathrm{~m}$, on tree bark in primary rainforest, 2012, Cáceres $\mathcal{E}$ Aptroot 11054, 11135.

\section{Astrothelium flavoduplex Aptroot \& M. Cáceres sp. nov.}

\section{MycoBank No.: MB 815167}

Astrothelium similar to $A$. mesoduplex, but with ascospores $110-350 \times 20-27 \mu \mathrm{m}$ and lichexanthone present in the thallus.

Type: Brazil, Rondônia, Porto Velho, Parque Natural Municipal de Porto Velho, $8^{\circ} 41^{\prime} 10^{\prime \prime S}, 63^{\circ} 52^{\prime} 05^{\prime \prime W}$, alt. c. $100 \mathrm{~m}$, on twig in primary rainforest, 19 November 2012, M. E. S. Cáceres Eீ A. Aptroot 15553 (ISEholotype; ABL-isotype).

\section{(Figs 2B \& 5P)}

Thallus corticate, smooth, somewhat shiny, continuous, covering areas $\leq 8 \mathrm{~cm}$ diam., c. $0.1 \mathrm{~mm}$ thick, olive-green, surrounded by a black prothallus line c. $0.3 \mathrm{~mm}$ wide, not inducing gall formation of the host bark.

Ascomata globose, $0.4-0.6 \mathrm{~mm}$ diam., immersed in groups of c. 7-50 in pseudostromata. Pseudostromata with a surface different from the thallus, c. $1 \mathrm{~mm}$ raised above the thallus, oval to irregular or reticulate in outline, $\leq c .3 \mathrm{~mm}$ wide, yellow to orange or brownish, pale yellow inside. Wall dark brown all around, $\leq c$. $40 \mu \mathrm{m}$ thick. Ostioles apical, not fused, flat to convex, brown. Hamathecium not inspersed with oil globules. Asci with 4-8 ascospores. Ascospores hyaline, muriform with c. 22-30 transverse septa, fusiform to clavate, $110-350 \times 20-27 \mu \mathrm{m}$, upper end rounded, lower end pointed, lumina angular with only a few transverse, mostly oblique septa, median septum much thickened at the sides, not surrounded by a gelatinous layer.

Pycnidia not observed.

Chemistry. Thallus surface UV+ yellow, thallus medulla $\mathrm{K}-$; pseudostroma surface and medulla UV+ red, K+ blood red. TLC: an anthraquinone, probably parietin.

Ecology and distribution. On smooth bark of trees in primary forest. Known only from Brazil.

Discussion. Similar to $A$. mesoduplex but with longer ascospores and lichexanthone. The length of the ascospores is very variable; in general they are longer when the asci are 

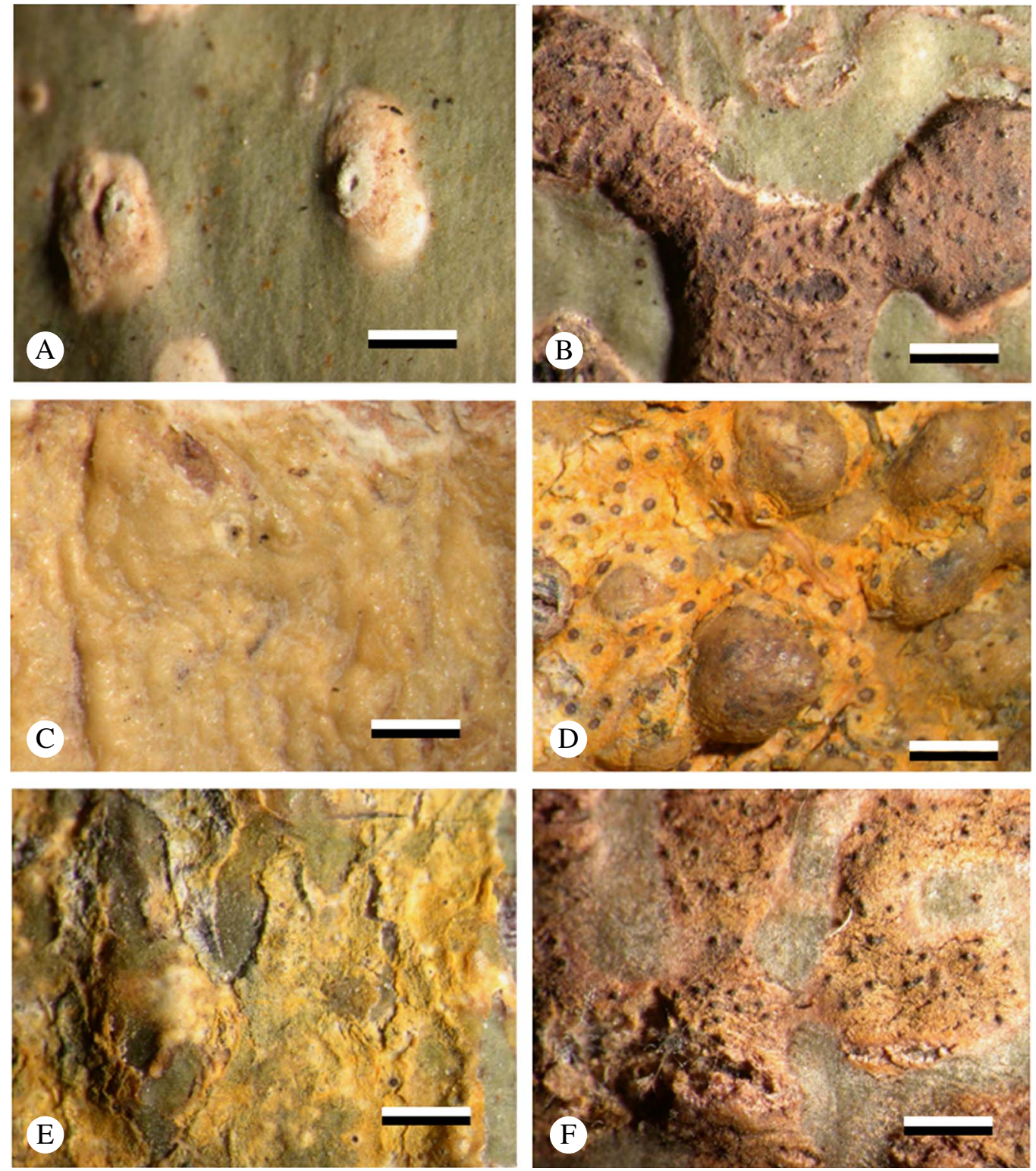

FIG. 2. Habitus of new species of Trypetheliaceae (isotypes). A, Astrothelium eustomurale; B, A. flavoduplex; C, A. flavomurisporum; D, A. flavostromatum; E, A. flavum; F, A. mesoduplex. Scales $=1 \mathrm{~mm}$. In colour online.

4-spored, compared with those from 8 -spored asci. This new species is widespread and locally common.

Additional material seen. Brazil: Rondônia: same as the type, M. E. S. Cáceres E A. Aptroot 15570, 15591a; ibid., 2012, M. E. S. Cáceres $\mathcal{E} A$. Aptroot 11251; same locality but in park near rainforest, 2012, M. E. S. Cáceres $\mathcal{E} A$. Aptroot
15184; Estação Ecológica de Cuniã, km 760 on road BR 319 NNE of Porto Velho, 802'44"S, 63²9'11"W, alt. c. $100 \mathrm{~m}$, on tree bark in primary rainforest, 2012 , M. E. S. Cáceres \& A. Aptroot 15622, 15704; Fazenda São Francisco off BR319, $30 \mathrm{~km} \mathrm{~N}$ of Porto Velho, $8^{\circ} 24^{\prime} 33^{\prime \prime S}$, 63 $3^{\circ} 58^{\prime} 56^{\prime \prime} \mathrm{W}$, alt. c. $100 \mathrm{~m}$, on tree bark in primary rainforest, 2012, M. E. S. Cáceres \& A. Aptroot 11836 (all ABL, ISE).-Guyana: Upper Takutu Distr.: 
c. $4 \mathrm{~km} \mathrm{~N}$ of Kuyuwini Landing, along track to Karaudanawa, 1992, Sipman 57045 (B).-Colombia: Amazonas: Araracuara, opposite Isla Mariñame, alt. 240 m, 1988, Sipman E Duivenvoorden 28339 (B).

\section{Astrothelium flavomurisporum Aptroot \& M. Cáceres sp. nov.}

MycoBank No.: MB 815168

Astrothelium with deeply immersed ascomata with muriform ascospores $165-200 \times 28-35 \mu \mathrm{m}$, with a distinctly thickened central septum and yellow oil.

Type: Brazil, Rondônia, Estação Ecológica de Cuniã, $\mathrm{km} 760$ on road BR 319 NNE of Porto Velho, $8^{\circ} 02^{\prime} 44^{\prime \prime S}$, $63^{\circ} 29^{\prime} 11^{\prime \prime} \mathrm{W}$, alt. c. $100 \mathrm{~m}$, on tree bark in primary rainforest, 20 November 2012, M. E. S. Cáceres $\mathcal{E} A$. Aptroot 15697 (ISE-holotype; ABL-isotype).

\section{(Figs 2C \& 5F)}

Thallus corticate, minutely bullate, somewhat shiny, continuous, covering areas $\leq 7 \mathrm{~cm}$ diam., c. $0.2 \mathrm{~mm}$ thick, olive-green, not surrounded by a prothallus, not inducing gall formation of the host bark.

Ascomata pyriform, 0.5-0.7 mm diam., 2-5 aggregated, deeply immersed in the bark, visible only from above by the ostioles, without pseudostroma. Wall carbonized, $\leq c .70 \mu \mathrm{m}$ thick. Ostioles eccentric, brown, flat to concave. Hamathecium not inspersed. Ascospores 8 per ascus, hyaline, muriform, long, ellipsoid, 165-200 $\times 28-35 \mu \mathrm{m}$, not surrounded by a gelatinous layer, lumina with yellow oil, central septum much thickened.

Pycnidia not observed.

Chemistry. Thallus and medulla UV-, K- . TLC: no secondary substances detected.

Ecology and distribution. On smooth bark of trees in primary forest. Known only from Brazil.

Discussion. This species is characterized by the deeply immersed ascomata with muriform ascospores with a distinctly thickened central septum and yellow oil. The species is most similar to $A$. cecidiogenum (Aptroot \& Lücking) Aptroot \& Lücking, which has hyaline and generally shorter ascospores. Ascospores with yellow oil are otherwise known only from Pseudopyrenula diluta.

\section{Astrothelium flavostromatum Aptroot \& M. Cáceres sp. nov.}

MycoBank No.: MB 815169

Astrothelium close to $A$. aeneoides Aptroot, mainly differing by the bullate thallus and the cream pseudostromata.

Type: Brazil, Rondônia, Porto Velho, Parque Natural Municipal de Porto Velho, $8^{\circ} 41^{\prime} 10^{\prime \prime S}, 63^{\circ} 52^{\prime} 05^{\prime \prime W}$, alt. c. $100 \mathrm{~m}$, on tree bark in park near rainforest, 16 November 2012, M. E. S. Cáceres \& A. Aptroot 15104 (ISE-holotype; ABL - isotype).

\section{(Figs 2D \& 5G)}

Thallus corticate, bullate, somewhat shiny, continuous, covering areas $\leq 5 \mathrm{~cm}$ diam., c. $0.2 \mathrm{~mm}$ thick, olive-green to olive-grey, not surrounded by a prothallus, inducing gall formation of the host bark.

Ascomata globose, $0.6-1.0 \mathrm{~mm}$ diam., immersed in groups of 5-25 in pseudostromata with a surface different from the thallus, which are not distinctly raised above the thallus and often even lower, linear to irregular in outline and often forming a network, cream with yellow pruina. Wall black all around, $\leq c .70 \mu \mathrm{m}$ thick. Ostioles apical, not fused, mostly concave, brown, often with a thin blackish rim. Hamathecium not inspersed with oil globules. Asci with 8 ascospores. Ascospores hyaline, 3-septate, fusiform, 23-25 $\times 9-10 \mu \mathrm{m}$, ends rounded, lumina diamond-shaped, surrounded by a gelatinous layer $\leq 5 \mu \mathrm{m}$ thick.

Pycnidia not observed.

Chemistry. Thallus surface UV-, thallus medulla $\mathrm{K}-$; pseudostroma surface UV+ pink to orange, pigmented parts of pseudostroma K+ blood red. TLC: an anthraquinone, probably parietin.

Ecology and distribution. On smooth bark of trees in park near rainforest. Known only from Brazil.

Discussion. This species is closest in key characters to $A$. aeneoides, and mainly differs by the bullate thallus and the cream pseudostromata.

\section{Astrothelium flavum Aptroot \& M. Cáceres sp. nov.}

\section{MycoBank No.: MB 815170}

Astrothelium similar to A. aeneum (Eschw.) Aptroot \& Lücking, but differing in the contrast between the linear 
to reticulate yellow stromata and the unpigmented thallus, and ascospores 16-18 $\times 6-7 \mu \mathrm{m}$.

Type: Brazil, Rondônia, Porto Velho, Parque Natural

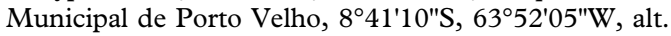
c. $100 \mathrm{~m}$, on tree bark in primary rainforest, 9-12 March 2012, M. E. S. Cáceres \& A. Aptroot 11410 (ISEholotype; ABL-isotype).

\section{(Figs $2 \mathrm{E} \& 5 \mathrm{H}$ )}

Thallus corticate, smooth, somewhat shiny, continuous, covering areas of $\leq 5 \mathrm{~cm}$ diam., c. $0.2 \mathrm{~mm}$ thick, olive-green to olivegrey, surrounded by a violet-brown prothallus line c. $0.3 \mathrm{~mm}$ wide, not inducing gall formation of the host bark.

Ascomata globose, $0.4-0.7 \mathrm{~mm}$ diam., immersed in groups of 5-25 in pseudostromata with a surface different from the thallus, and which are slightly raised above the thallus, irregular to linear or reticulate in outline, $\leq c .3 \mathrm{~mm}$ wide, bright yellow, inside with bark tissue. Wall dark brown all around, $\leq c .40 \mu \mathrm{m}$ thick. Ostioles apical, not fused, flat to concave, black. Hamathecium not inspersed with oil globules. Asci with 8 ascospores. Ascospores hyaline, 3-septate, fusiform, 16-18 $\times$ 6-7 $\mu \mathrm{m}$, ends rounded, lumina diamondshaped, not surrounded by a gelatinous layer.

Pycnidia not observed.

Chemistry. Thallus surface UV-, thallus medulla $\mathrm{K}-$; pseudostroma surface UV+ red, K+ blood red. TLC: an anthraquinone, probably parietin.

Ecology and distribution. On smooth bark of trees in primary forest. Known only from Brazil.

Discussion. This species is similar to $A$. aeneum, but differs in the contrast between the linear to reticulate yellow stromata and the non-pigmented thalli, and the relatively small ascospores.

\section{Astrothelium mesoduplex Aptroot \& M. Cáceres sp. nov.}

\section{MycoBank No.: MB 815171}

Astrothelium similar to A. flavoduplex, but ascospores 90$100 \times 20-23 \mu \mathrm{m}$ and the thallus is without lichexanthone.

Type: Brazil, Rondônia, Porto Velho, Parque Natural Municipal de Porto Velho, $8^{\circ} 41^{\prime} 10^{\prime \prime}$, 635' $52^{\prime} 05^{\prime \prime W}$, alt. c. $100 \mathrm{~m}$, on twig in primary rainforest, 19 November
2012, M. E. S. Cáceres \& A. Aptroot 15559 (ISEholotype; ABL - isotype).

(Fig. 2F)

Thallus corticate, smooth, somewhat shiny, continuous, covering areas $\leq 8 \mathrm{~cm}$ diam., c. $0.1 \mathrm{~mm}$ thick, olive-green, surrounded by a black prothallus line $c .0 .2 \mathrm{~mm}$ wide, not inducing gall formation of the host bark.

Ascomata globose, $0.4-0.6 \mathrm{~mm}$ diam., immersed in groups of c. 3-50 in pseudostromata. Pseudostromata with a surface different from the thallus, c. $1 \mathrm{~mm}$ raised above the thallus, oval to irregular in outline, $\leq c .3 \mathrm{~mm}$ wide, yellow to orange, pale yellow inside. Wall dark brown all around, $\leq c$. $40 \mu \mathrm{m}$ thick. Ostioles apical, not fused, flat to convex, brown. Hamathecium not inspersed with oil globules. Asci with 8 ascospores. Ascospores hyaline, muriform with c. 22-30 transverse septa, fusiform to clavate, $90-100 \times 20-23 \mu \mathrm{m}$, ends rounded, lumina angular with mostly oblique septa, not surrounded by a gelatinous layer.

\section{Pycnidia not observed.}

Chemistry. Thallus surface UV-, thallus medulla $\mathrm{K}-$; pseudostroma surface and medulla UV+ red, $\mathrm{K}+$ blood red. TLC: an anthraquinone, probably parietin.

Ecology and distribution. On smooth bark of trees in primary forest. Known only from Brazil.

Discussion. Similar to $A$. flavoduplex which has longer ascospores and contains lichexanthone. The new species is locally common.

Additional material seen (all ABL, ISE). Brazil: same as the type, 15555, 15591o; ibid., 2012, M. E. S. Cáceres \& A. Aptroot 11253, 11254; Rondônia, Fazenda São Francisco off BR319, $30 \mathrm{~km} \mathrm{~N}$ of Porto Velho, 8²4'33"S, $63^{\circ} 58^{\prime} 56^{\prime \prime W}$, alt. c. $100 \mathrm{~m}$, on tree bark in primary rainforest, 2012, M. E. S. Cáceres \& A. Aptroot 11958.

\section{Astrothelium nigrum Aptroot \& M. Cáceres sp. nov.}

\section{MycoBank No.: MB 815174}

Astrothelium characterized by the mostly conical black pseudostromata that contrast sharply with the thallus, superficially resembling Pyrenula infraleucotrypa Aptroot \& M. Cáceres.

Type: Brazil, Rondônia, Estação Ecológica de Cuniã, $\mathrm{km} 760$ on road BR 319 NNE of Porto Velho, $8^{\circ} 02^{\prime} 44^{\prime \prime}$, $63^{\circ} 29^{\prime} 11^{\prime \prime W}$, alt. c. $100 \mathrm{~m}$, on tree bark in primary 
rainforest, 20 November 2012, M. E. S. Cáceres E A. Aptroot 15703 (ISE-holotype; ABL-isotype).

\section{(Fig. 3A \& B)}

Thallus corticate, smooth, somewhat shiny, continuous, covering areas $\leq 10 \mathrm{~cm}$ diam., c. $0.1 \mathrm{~mm}$ thick, ochraceous green, surrounded by a black prothallus line $c .0 .4 \mathrm{~mm}$ wide, inducing gall formation of the host bark in the form of making the bark pieces become slightly concave and thickened along the cracks so that they are almost flaking off.

Ascomata pyriform, $0.2-0.4 \mathrm{~mm}$ wide, $0.5-0.7 \mathrm{~mm}$ high, mostly 4-16 aggregated, immersed in conical to hemispherical pseudostromata with a black surface which is not corticated; pseudostromata distinctly raised above the thallus, regular in outline, sides sloping, $\leq c .2 \mathrm{~mm}$ diam. and $0.7 \mathrm{~mm}$ high, consisting of carbonized bark tissue. Wall carbonized all around, $\leq c .100 \mu \mathrm{m}$ thick. Ostioles eccentric, fused, flat to convex, black, surrounded by a dull grey pruinose rim. Hamathecium not inspersed with oil globules. Asci with 8 ascospores. Ascospores hyaline, 3-septate, fusiform, 19-21× $7-8 \mu \mathrm{m}$, ends rounded, lumina diamondshaped, not surrounded by a gelatinous layer.

Pycnidia not observed.

Chemistry. Thallus surface UV-, thallus medulla $\mathrm{K}-$; pseudostroma $\mathrm{UV}-, \mathrm{K}-$. TLC: no secondary substances detected.

Ecology and distribution. On smooth bark of trees in primary forest. Known only from Brazil.

Discussion. Unique in the mostly conical black pseudostromata that contrast sharply with the thallus, superficially giving it the impression of a Pyrenula species such as $P$. infraleucotrypa. No other Trypetheliaceae is close in appearance.

\section{Astrothelium novemseptatum Aptroot \& M. Cáceres sp. nov.}

\section{MycoBank No.: MB 815175}

Astrothelium similar to $A$. eumultiseptatum Aptroot \& $M$. Cáceres, but without lichexanthone anywhere in the thallus or pseudostroma.

Type: Brazil, Rondônia, Porto Velho, Parque Natural Municipal de Porto Velho, $8^{\circ} 41^{\prime} 10^{\prime \prime}$, 6 6 $3^{\circ} 52^{\prime} 05^{\prime \prime W}$, alt. c. $100 \mathrm{~m}$, on tree bark in primary rainforest,
9-12 March 2012, M. E. S. Cáceres E A. Aptroot 11538 (ISE-holotype; ABL-isotype).

\section{(Figs 3C \& 5I)}

Thallus corticate, smooth, somewhat shiny, continuous, covering areas $\leq 7 \mathrm{~cm}$ diam., c. $0.2 \mathrm{~mm}$ thick, pale greenish grey, with or without a black prothallus line c. $0.3 \mathrm{~mm}$ wide, inducing infrequent semiglobose galls of the host bark (lower bark locally swollen and erupting through bark).

Ascomata pyriform, c. $0.4-0.7 \mathrm{~mm}$ diam., mostly aggregated with $4-10$, mostly immersed in the bark tissue below pseudostromata with a whitish surface different from the thallus, and which are distinctly raised above the thallus and mostly oval in outline, and $\leq 3 \mathrm{~mm}$ wide and $\leq 6 \mathrm{~mm}$ long. Wall carbonized, $\leq c .40 \mu \mathrm{m}$ thick. Ostioles eccentric, fused, flat, pale brown, surrounded by a whitish zone. Hamathecium not inspersed with oil globules. Asci with 8 ascospores. Ascospores hyaline, 9-septate, fusiform, $49-55 \times 12-17 \mu \mathrm{m}$, ends pointed, lumina diamond-shaped, when fresh surrounded by a gelatinous layer $\leq 8 \mu \mathrm{m}$ thick.

Pycnidia not observed.

Chemistry. Thallus surface UV-, thallus medulla $\mathrm{K}-$; pseudostroma UV-, K-. TLC: no secondary substances detected.

Ecology and distribution. On smooth bark of trees in primary forest. Known from Brazil, Guyana and Colombia.

Discussion. This species is most similar to $A$. eumultiseptatum (see above), which however has lichexanthone on the ostioles.

Additional specimens seen. Guyana: Essequibo River, Gunn's, 1989, Fansen-Facobs et al. 1868 (ABL, L); Potaro-Siparuni Region, Kaieteur Falls National Park, around airstrip, Sipman 40456, 1996 (B).-Colombia: Amazonas: Araracuara, opposite airstrip, alt. $350 \mathrm{~m}$, 1988, Sipman \& Duivenvoorden 27867 (B).

\section{Astrothelium ochroleucoides Aptroot \& M. Cáceres sp. nov.}

\section{MycoBank No.: MB 815176}

Astrothelium similar to $A$. corallinum Aptroot, but with lichexanthone on the thallus and pseudostromata.

Type: Brazil, Rondônia, Estação Ecológica de Cuniã, $\mathrm{km} 760$ on road BR $319 \mathrm{NNE}$ of Porto Velho, $8^{\circ} 02^{\prime} 44^{\prime \prime S}$, 

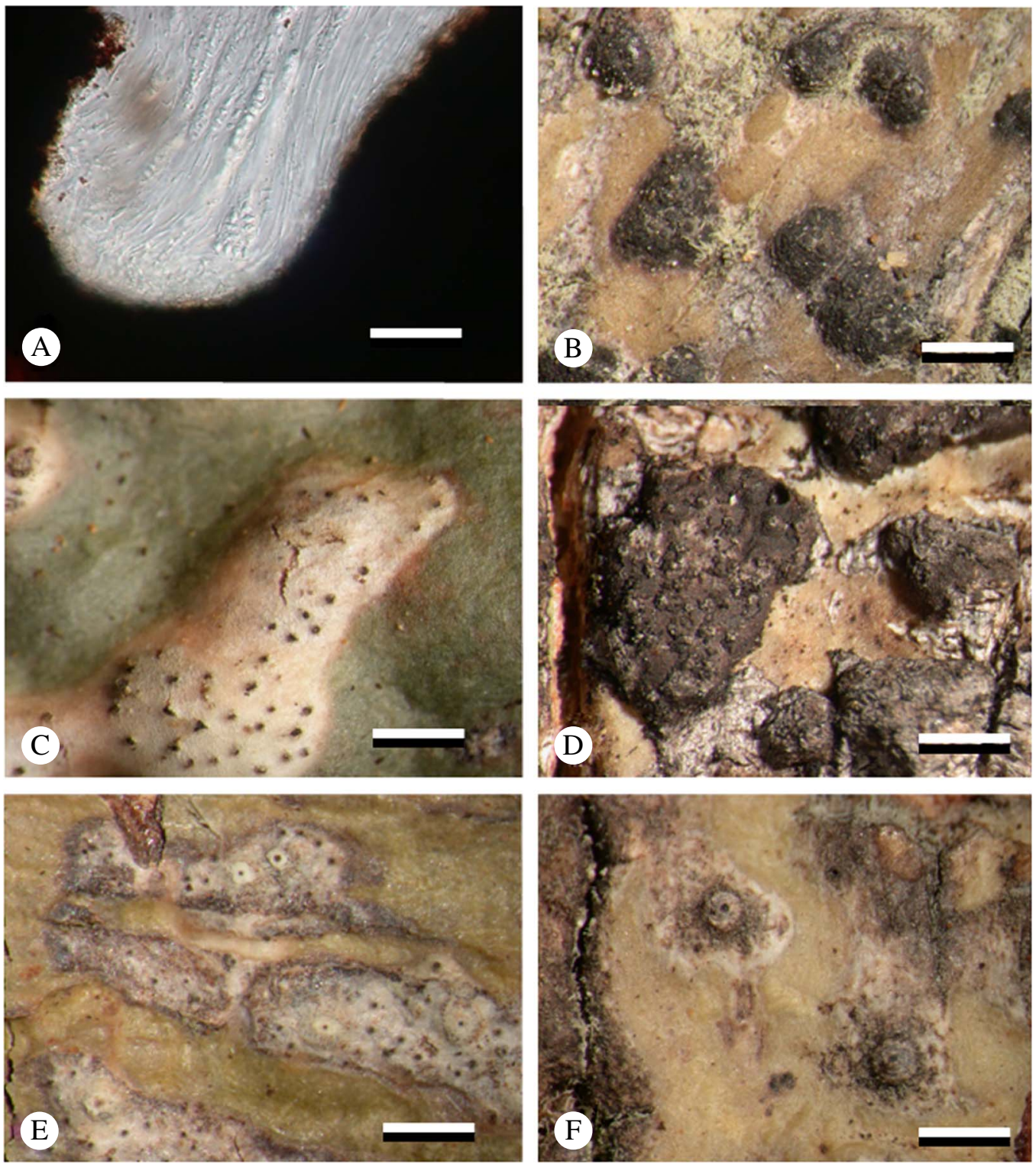

Fig. 3. Habitus (except 3A) of new species of Trypetheliaceae, (isotypes). A, Astrothelium nigrum, section showing full carbonization; B, A. nigrum; C, A. novemseptatum; D, A. ochroleucoides; E, A. octoseptatum; $\mathrm{F}$, A. quatuorseptatum. Scales: $\mathrm{A}=40 \mu \mathrm{m} ; \mathrm{B}-\mathrm{F}=1 \mathrm{~mm}$. In colour online.

$63^{\circ} 29^{\prime} 11^{\prime \prime W}$, alt. c. $100 \mathrm{~m}$, on tree bark in primary rainforest, 20 November 2012, M. E. S. Cáceres \& A. Aptroot 15705 (ISE-holotype; ABL-isotype).

(Fig. 3D)

Thallus corticate, smooth, somewhat shiny, continuous, covering areas $\leq 8 \mathrm{~cm}$ diam., c. $0.1 \mathrm{~mm}$ thick, olive-green, surrounded by a black prothallus line c. $0.3 \mathrm{~mm}$ wide, not inducing gall formation of the host bark.

Ascomata globose, $0.4-0.6 \mathrm{~mm}$ diam., immersed in groups of c. 2-40 in pseudostromata. Pseudostroma with a surface different from the thallus, c. $0.5-1.0 \mathrm{~mm}$ raised 
above the thallus, oval to irregular or reticulate in outline, $\leq c .3 \mathrm{~mm}$ wide, brownish black, usually partly with whitish cover, partly brownish, partly whitish inside. Wall dark brown all around, $\leq$ c. $40 \mu \mathrm{m}$ thick. Ostioles apical, not fused, flat to convex, brown. Hamathecium not inspersed with oil globules. Asci with 4 ascospores. Ascospores hyaline, muriform, fusiform, $80-115 \times 15-24 \mu \mathrm{m}$, upper end rounded, lower end pointed, lumina angular with only a few transverse, mostly oblique septa, not surrounded by a gelatinous layer.

Pycnidia not observed.

Chemistry. Thallus surface UV+ yellow, thallus medulla $\mathrm{K}-$; whitish parts of pseudostroma surface UV+ yellow, K-, pseudostroma medulla K-. TLC: lichexanthone in the thallus and on pseudostroma.

Ecology and distribution. On twigs or bark of tree trunks in primary forest, but also in parks and savannahs. Known from Brazil and Guyana where it is locally abundant.

Discussion. This species differs from A. duplicatum, A. flavoduplex and A. mesoduplex, all described above, by the blackish pseudostroma and the absence of anthraquinones. It is most similar to A. corallinum Aptroot, which differs by the UV- thallus. These two species grow together in close contact in Guyana. The new species is widespread and locally common.

Additional material seen. Brazil: Rondônia: Porto Velho, Parque Natural Municipal de Porto Velho, alt. c. $100 \mathrm{~m}$, on twig in primary rainforest, 2012, Cáceres $\mathcal{E}$ Aptroot 15559 (ISE, ABL); same locality but in park near rainforest, 2012, Cáceres \& Aptroot 15166, 15169, 15173, 15174, 15176, 15177 (all ISE, ABL). Mato Grosso: Jaciara-Sao Vicente, Kalb, 1980 (hb. Kalb).Guyana: East Demarara: Timehri, Dakara Creek, Thompson's farm, 1985, Sipman E A Aptroot 18951 \& 18051 (ABL, B); along Linden highway, Soesdyke, 1996, Sipman 40261 (B); along Linden highway E of Timehri airport., alt. $10 \mathrm{~m}, 1985$, Sipman $\mathcal{E}$ Aptroot 19603 (B, ABL). Upper Takutu: Rupununi Savannah, Kusad Mountain, 1992, Sipman 57826 (B); Kuyuwini Landing, 1992, Sipman 57057, 57120, $57121 \& 57053$ (B). Potaro-Siparuni Region: surroundings of Paramakatoi Village, alt. $800 \mathrm{~m}, 1996$, Sipman 41275pp (B).

\section{Astrothelium octoseptatum Aptroot \& M. Cáceres sp. nov.}

\section{MycoBank No.: MB 815177}

Astrothelium similar to A. eumultiseptatum Aptroot \& M. Cáceres, but with the whole pseudostroma, not just the ostioles, containing lichexanthone; ascospores somewhat asymmetrical, which is highlighted by the unusual dominant even number of septa (eight) and the asymmetrically placed central septum in the case of uneven septum numbers.

Type: Brazil, Rondônia, Porto Velho, Parque Natural Municipal de Porto Velho, $8^{\circ} 41^{\prime} 10^{\prime \prime} \mathrm{S}, 63^{\circ} 52^{\prime} 05^{\prime \prime} \mathrm{W}$, alt. c. $100 \mathrm{~m}$, on tree bark in primary rainforest, 19 November 2012, M. E. S. Cáceres \& A. Aptroot 15614 (ISEholotype; ABL-isotype).

\section{(Figs 3E \& 5J)}

Thallus corticate, smooth, somewhat shiny, continuous, covering areas $\leq 7 \mathrm{~cm}$ diam., c. $0 \cdot 1 \mathrm{~mm}$ thick, pale greenish grey, not surrounded by a prothallus, not inducing gall formation of the host bark.

Ascomata pyriform, c. $0.6-0.9 \mathrm{~mm}$ diam., mostly 2-5 aggregated, mostly immersed in the bark tissue below pseudostromata. Pseudostroma well delimited, not corticate, brown with a whitish (partly brown when abraded) surface clearly different from the thallus, distinctly $c .0 .5 \mathrm{~mm}$ raised above the thallus, $\leq 3 \mathrm{~mm}$ wide and $\leq 7 \mathrm{~mm}$ long, irregular in outline and sometimes forming a network. Wall brown, $\leq$ c. $30 \mu \mathrm{m}$ thick. Ostioles eccentric, fused, flat, brown, surrounded by a whitish zone. Hamathecium not inspersed with oil globules. Asci with 8 ascospores. Ascospores hyaline, (7-)8(-9)-septate, fusiform, 40-57 × 15-19 $\mu \mathrm{m}$, middle septum (if present) asymmetrical (dividing the ascospore into two unequal parts), ends rounded, lumina diamond-shaped, surrounded by a gelatinous layer $\leq 7 \mu \mathrm{m}$ thick.

Pycnidia abundant, black, only on the pseudostromata.

Chemistry. Thallus surface UV-, thallus medulla $\mathrm{K}-$; pseudostroma surface UV+ yellow. TLC: lichexanthone.

Ecology and distribution. On smooth bark of trees in primary forest. Known only from Brazil.

Discussion. Somewhat similar to $A$. eumultiseptatum (see above), in which only the 
ostioles contain lichexanthone. The ascospores of this species are somewhat asymmetrical, which is highlighted by the unusual dominant even number of septa (eight) and the asymmetrically placed central septum in the case of uneven septum numbers.

Additional specimen seen. Brazil: Rondônia: Estação Ecológica de Cuniã, km 760 on road BR 319 NNE of Porto Velho, $8^{\circ} 02^{\prime} 44^{\prime \prime S}, 63^{\circ} 29^{\prime} 11^{\prime \prime W}$, alt. c. $100 \mathrm{~m}$, on tree bark in primary rainforest, 2012, Cáceres $\mathcal{E}$ Aptroot 15831 (ISE, ABL).

\section{Astrothelium quatuorseptatum Aptroot \& M. Cáceres sp. nov.}

MycoBank No.: MB 815179

Astrothelium similar to $A$. octoseptatum Aptroot \& M. Cáceres, but without lichexanthone; ascospores somewhat asymmetrical, which is highlighted by the unusual dominant even number of septa (four) and the asymmetrically placed central septum in the case of uneven septum numbers.

Type: Brazil, Rondônia, Estação Ecológica de Cuniã, $\mathrm{km} 760$ on road BR 319 NNE of Porto Velho, $8^{\circ} 02^{\prime} 44^{\prime \prime} \mathrm{S}$, $63^{\circ} 29^{\prime} 11^{\prime \prime W}$, alt. c. $100 \mathrm{~m}$, on tree bark in primary rainforest, 20 November 2012, M. E. S. Cáceres $\mathcal{E}$ A. Aptroot 15717 (ISE-holotype; ABL-isotype).

\section{(Figs $3 \mathrm{~F} \& 5 \mathrm{~K}$ )}

Thallus corticate, smooth, somewhat shiny, continuous, covering areas $\leq 7 \mathrm{~cm}$ diam., c. $0.1 \mathrm{~mm}$ thick, pale greenish grey, surrounded by a prothallus line c. $0.1 \mathrm{~mm}$ wide, inducing gall formation of the host bark in the form of making the bark pieces become slightly concave and thickened along the cracks so that they are almost flaking off.

Ascomata pyriform, c. $0 \cdot 6-0.8 \mathrm{~mm}$ diam., mostly 2-5 aggregated, mostly immersed in the bark tissue below pseudostromata. Pseudostroma well delimited, not corticate, brown, occasionally with a whitish (usually abraded) surface clearly different from the thallus, distinctly c. $0.3 \mathrm{~mm}$ raised above the thallus, $\leq 2 \mathrm{~mm}$ diam., rounded to somewhat irregular in outline. Wall brown, $\leq c .30 \mu \mathrm{m}$ thick. Ostioles eccentric, fused, flat to convex, brown, surrounded by a whitish grey zone. Hamathecium not inspersed with oil globules. Asci with 8 ascospores. Ascospores hyaline, (3-)4(-5)-septate, fusiform, 45$55 \times 15-18 \mu \mathrm{m}$, middle septum (if present) asymmetrical (dividing the ascospore into two unequal parts), ends rounded, lumina diamond-shaped, not surrounded by a gelatinous layer.

Pycnidia not observed.

Chemistry. Thallus surface UV-, thallus medulla $\mathrm{K}-$; pseudostroma UV-, K-. TLC: no secondary substances detected.

Ecology and distribution. On smooth bark of trees in primary forest. Known only from Brazil.

Discussion. Similar to A. octosporum (see above) in the asymmetrical ascospores, but with only half the number of septa and without lichexanthone.

\section{Astrothelium robustosporum Aptroot \& M. Cáceres sp. nov.}

\section{MycoBank No.: MB 815180}

Astrothelium with solitary ascomata with an eccentric ostiole, ascospores 11-15-septate, 90-125 × 20-27 $\mu \mathrm{m}$.

Type: Brazil, Rondônia, Estação Ecológica de Cuniã, $\mathrm{km} 760$ on road BR 319 NNE of Porto Velho, $8^{\circ} 02^{\prime} 44^{\prime \prime S}$, $63^{\circ} 29^{\prime} 11^{\prime \prime} \mathrm{W}$, alt. c. $100 \mathrm{~m}$, on tree bark in primary rainforest, 13 March 2012, M. E. S. Cáceres E A. Aptroot 11696 (ISE-holotype; ABL-isotype).

\section{(Figs 4A \& 5L)}

Thallus corticate, smooth, dull, continuous but locally abraded, covering areas $\leq 10 \mathrm{~cm}$ diam., c. $0.1 \mathrm{~mm}$ thick, pale ochraceous green, not surrounded by a prothallus, not inducing gall formation of the host bark.

Ascomata pyriform (somewhat triangular in horizontal section), $0.6-0.9 \mathrm{~mm}$ wide, $0.7-$ $1.1 \mathrm{~mm}$ long, solitary, completely immersed in the bark, without visible pseudostromata or swellings. Wall carbonized all around, $\leq c$. $60 \mu \mathrm{m}$ thick. Ostioles eccentric, simple, flat to convex, black, presenting the only part of the ascoma that is visible from above. Hamathecium not inspersed with oil globules. Asci with 8 ascospores. Ascospores hyaline, 11-15septate, fusiform, $90-125 \times 20-27 \mu \mathrm{m}$, pointed, lumina diamond-shaped, surrounded by a gelatinous layer $\leq 10 \mu \mathrm{m}$ thick, central septum much thickened at the sides.

Pycnidia not observed with certainty, although some of the black dots around the ostioles may represent young pycnidia. 

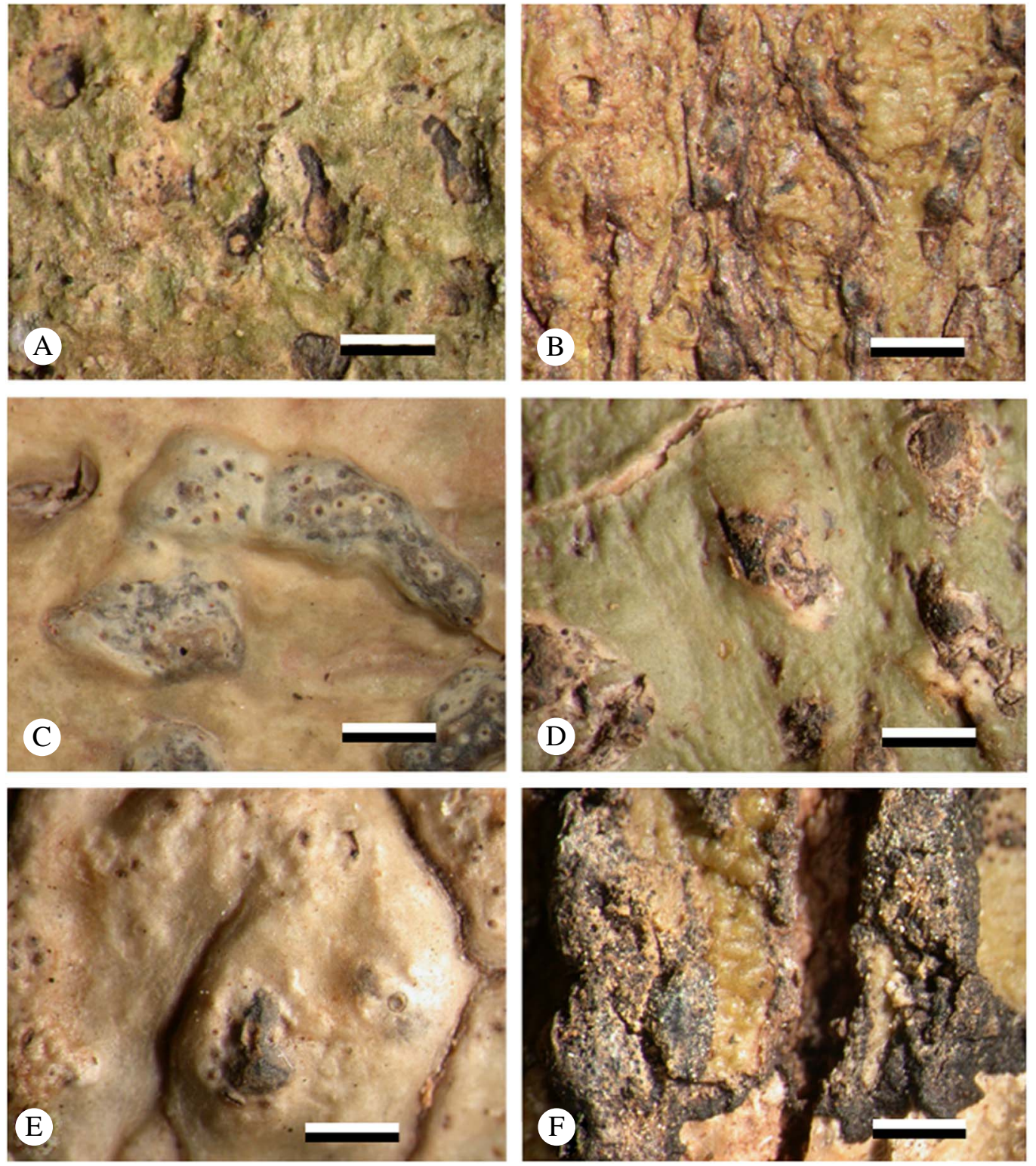

Fig. 4. Habitus of new species of Trypetheliaceae, (isotypes). A, Astrothelium robustosporum; B, A. solitarium; C, A. stromatofluorescens; D, A. supraclandestinum; E, A. testudineum; F, A. xanthosuperbum. Scales $=1 \mathrm{~mm}$. In colour online.

Chemistry. Thallus and medulla UV-, $\mathrm{K}-$. TLC: no secondary substances detected.

Ecology and distribution. On smooth bark of trees in primary forest. Known only from Brazil.
Discussion. This species resembles some Astrothelium species that were formerly in Campylothelium (such as A. puiggarii (Müll. Arg.) Aptroot \& Lücking) in gross morphology due to the solitary ascomata with eccentric ostiole, but it has large ascospores that are only 

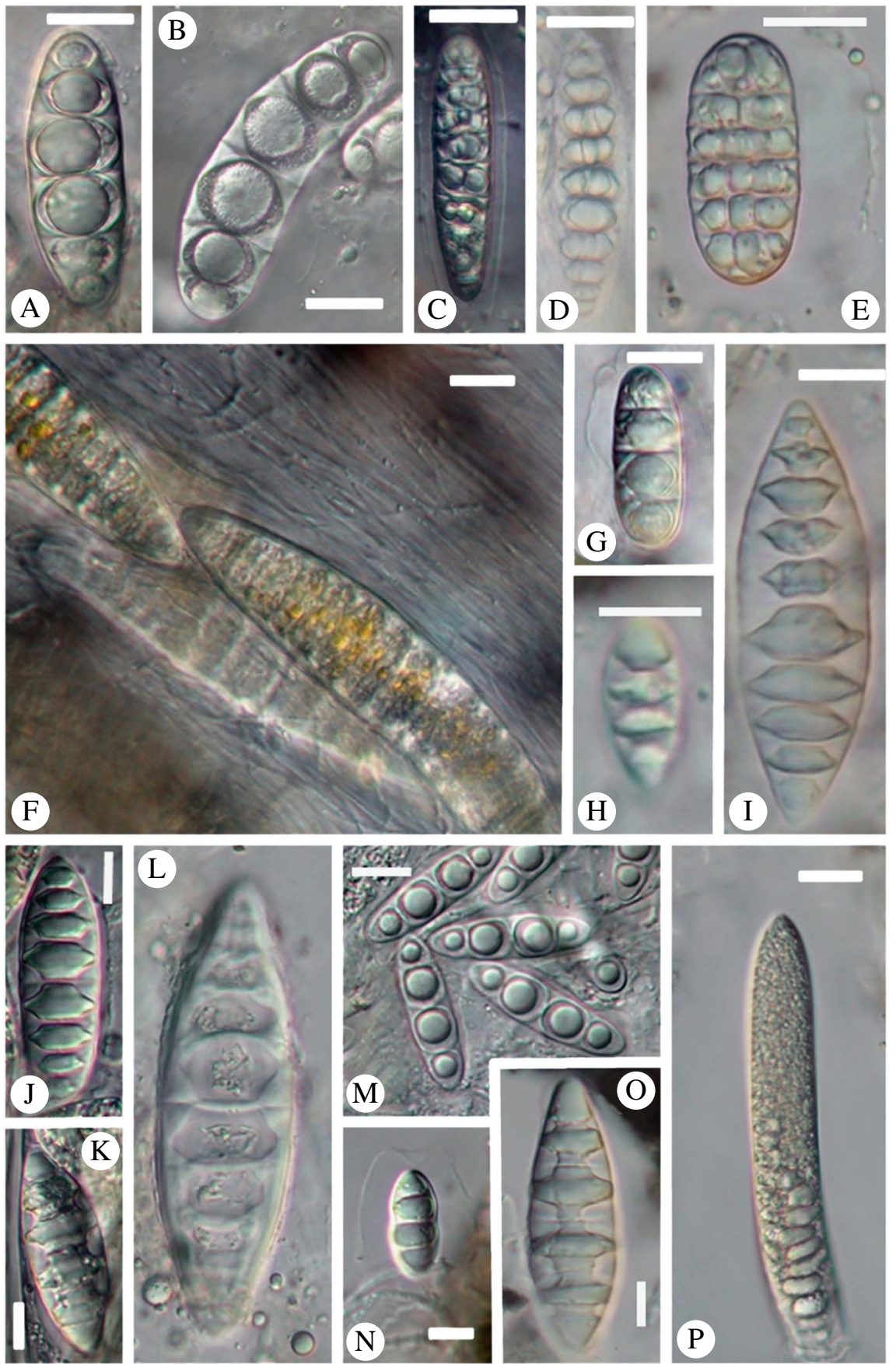

FIG. 5. Ascospores of new species of Trypetheliaceae, (isotypes). A, Astrothelium bivelum; B, A. curvisporum; C, A. decemseptatum; D, A. eumultiseptatum; E, A. eustomurale; F, A. flavomurisporum; G, A. flavostromatum; $\mathrm{H}, A$. flavum; I, A. novemseptatum; J, A. octoseptatum; K, A. quatuorseptatum; L, A. robustosporum; M, $A$. solitarium; $\mathrm{N}, A$. stromatofluorescens; O, A. supraclandestinum; P, A. flavoduplex. Scales: A-F \& $\mathrm{P}=20 \mu \mathrm{m} ; \mathrm{G}-\mathrm{O}=10 \mu \mathrm{m}$. In colour online. 
transversely septate rather than muriform as in all former Campylothelium species. The new species is most similar to $A$. basilicum (Krempelh.) Aptroot \& Lücking, which has longer ascospores.

\section{Astrothelium solitarium Aptroot \& M. Cáceres sp. nov.}

\section{MycoBank No.: MB 815181}

Astrothelium similar to A. ceratinum (Fée) Aptroot \& Lücking, but with ascospores 33-36 $\times 10-11 \mu \mathrm{m}$.

Type: Brazil, Rondônia, Porto Velho, Parque Natural Municipal de Porto Velho, 8 41'10"S, 6352'05"W, alt. c. $100 \mathrm{~m}$, on tree bark in primary rainforest, 19 November 2012, M. E. S. Cáceres \& A. Aptroot 15501 (ISEholotype; ABL - isotype).

\section{(Figs 4B \& 5M)}

Thallus corticate, smooth, shiny, continuous, covering areas $\leq 3 \mathrm{~cm}$ diam., under $0.1 \mathrm{~mm}$ thick, olive-green, surrounded by a dark brown prothallus line $c .0 .1 \mathrm{~mm}$ wide, not inducing gall formation of the host bark.

Ascomata globose, $0.3-0.5 \mathrm{~mm}$ diam., solitary or in groups of 2-4, erumpent from the bark, black, partly with irregular thallus coverage, not in pseudostromata. Wall black all around, $\leq$ c. $30 \mu \mathrm{m}$ thick. Ostioles apical, not fused, flat, dark brown, often surrounded by a pale brown ring. Hamathecium not inspersed with oil globules. Asci with 8 ascospores. Ascospores hyaline, 3-septate, fusiform, 33-36 × 10-11 $\mu \mathrm{m}$, ends rounded, lumina diamond-shaped, not surrounded by a gelatinous layer.

Pycnidia not observed.

Chemistry. Thallus and medulla UV-, K-. TLC: no secondary substances detected.

Ecology and distribution. On smooth bark of trees in primary forest. Known only from Brazil.

Discussion. This species is most similar to A. ceratinum, which has smaller ascospores.

\section{Astrothelium stromatofluorescens Aptroot \& M. Cáceres sp. nov.}

\section{MycoBank No.: MB 815183}

Astrothelium close to A. phlyctaena (Fée) Aptroot \& Lücking, but with lichexanthone only on the pseudostroma, not on the thallus.
Type: Brazil, Rondônia, Porto Velho, Parque Natural Municipal de Porto Velho, $8^{\circ} 41^{\prime} 10^{\prime \prime S}, 63^{\circ} 52^{\prime} 05^{\prime \prime} \mathrm{W}$, alt. c. $100 \mathrm{~m}$, on tree bark in park near rainforest, 16 November 2012, M. E. S. Cáceres E A. Aptroot 15224 (ISE-holotype; ABL-isotype).

\section{(Figs 4C \& 5N)}

Thallus corticate, smooth, somewhat shiny, continuous, covering areas $\leq 7 \mathrm{~cm}$ diam., c. $0 \cdot 1 \mathrm{~mm}$ thick, pale ochraceous green, surrounded by a black prothallus line c. $0.2 \mathrm{~mm}$ wide, not inducing gall formation of the host bark.

Ascomata globose, $0.2-0.5 \mathrm{~mm}$ diam., immersed in groups of 7-50 in pseudostromata, not all reaching the surface at one time. Pseudostromata well delimited, not corticate, slate grey with a whitish (partly slate grey when abraded) surface clearly different from the thallus, distinctly c. $1 \mathrm{~mm}$ raised above the thallus, $\leq 7 \mathrm{~mm}$ diam., irregular in outline and sometimes forming a network, inside with carbonized bark tissue. Wall black, $\leq c .30 \mu \mathrm{m}$ thick. Ostioles apical, not fused, flat to concave, ferrugineous brown, surrounded by a whitish zone. Hamathecium not inspersed with oil globules. Asci with 8 ascospores. Ascospores hyaline, 3-septate, fusiform, 20-23 $\times 7-9 \mu \mathrm{m}$, ends rounded, lumina diamond-shaped, surrounded by a gelatinous layer $\leq 6 \mu \mathrm{m}$ thick.

Pycnidia not observed.

Chemistry. Thallus surface UV-, thallus medulla $\mathrm{K}-$; pseudostroma surface $\mathrm{UV}+$ yellow. TLC: lichexanthone.

Ecology and distribution. On bark of trees in park near rainforest. Known only from Brazil.

Discussion. This species is close to $A$. phlyctaenum, which has lichexanthone not only on the pseudostroma, but also on the thallus.

\section{Astrothelium supraclandestinum Aptroot \& M. Cáceres sp. nov.}

\section{MycoBank No.: MB 815185}

Astrothelium close to $A$. subclandestinum Leight., but hamathecium not inspersed.

Type: Brazil, Rondônia, Porto Velho, Parque Natural

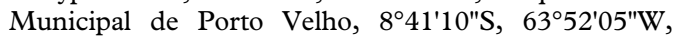
alt. c. $100 \mathrm{~m}$, on tree bark in primary rainforest, 
9-12 March 2012, M. E. S. Cáceres E A. Aptroot 11344 (ISE-holotype; ABL-isotype).

(Figs 4D \& 5O)

Thallus corticate, smooth to somewhat bullate, somewhat shiny, continuous, covering areas $\leq 7 \mathrm{~cm}$ diam., c. $0.1 \mathrm{~mm}$ thick, greenish grey, surrounded by a prothallus line c. $0.2 \mathrm{~mm}$ wide, infrequently inducing semiglobose galls of the host bark (lower bark locally swollen and erupting through bark).

Ascomata pyriform, c. $0.5-0.8 \mathrm{~mm}$ diam., mostly $2-5$ aggregated, mostly immersed in the bark tissue below pseudostromata. Pseudostromata indistinctly delimited, not corticate, ochraceous or concolorous with the thallus, not much raised above the thallus, $\leq 2 \mathrm{~mm}$ diam., rounded to somewhat irregular in outline. Wall black, $\leq c .60 \mu \mathrm{m}$ thick. Ostioles eccentric, fused, flat to convex, brown to black. Hamathecium not inspersed with oil globules. Asci with 8 ascospores. Ascospores hyaline, 5-septate, fusiform, 50-75 $\times 14-22 \mu \mathrm{m}$, ends rounded, lumina diamond-shaped, surrounded by a gelatinous layer $\leq 2 \mu \mathrm{m}$ thick.

Pycnidia frequent, in the pseudostromata.

Chemistry. Thallus surface UV-, thallus medulla $\mathrm{K}-$; pseudostroma UV-, K-. TLC: no secondary substances detected.

Ecology and distribution. On smooth bark of trees in primary forest. Known from Brazil, Venezuela, Australia and Papua New Guinea.

Discussion. This species is close to $A$. subclandestinum, which has an inspersed hamathecium. It is widespread.

Additional material seen. Brazil: same as the type, 11343 (ISE, ABL).-Venezuela: Amazonas: Alto Orinoco, Surumoni, 1998, Hafellner E Komposch 313-5-48, 313-549, 28-21, 17-2 \& 3175 (GZU).-Australia: Queensland: Millaa Millaa, Hale 64166 (ABL, US).-Papua New Guinea: Madang: foothills of Finisterre Range, along road Madang-Lae, km 39, 1992, Aptroot 33209 (ABL).

\section{Astrothelium testudineum Aptroot \& M. Cáceres sp. nov.}

\section{MycoBank No.: MB 815186}

Astrothelium with solitary ascomata with an eccentric ostiole, inspersed hamathecium, ascospores 8 per ascus, muriform, 50-65 × 23-27 $\mu \mathrm{m}$.
Type: Brazil, Rondônia, Porto Velho, Parque Circuito, $8^{\circ} 43^{\prime} 54^{\prime \prime S}, 63^{\circ} 54^{\prime} 04^{\prime \prime W}$, alt. c. $100 \mathrm{~m}$, on Hevea brasiliensis bark in plantation, 8 March 2012, M. E. S. Cáceres E A. Aptroot 11448a (ISE-holotype; ABLisotype).

(Fig. 4E)

Thallus thickly corticate, smooth, somewhat shiny, continuous, covering areas $\leq 5 \mathrm{~cm}$ diam., c. $0.2 \mathrm{~mm}$ thick, ochraceous, surrounded by a black prothallus line c. $0 \cdot 1 \mathrm{~mm}$ wide, not inducing gall formation of the host bark.

Ascomata pyriform, $0.5-0.9 \mathrm{~mm}$ diam., mostly 2-6 aggregated, immersed in the thallus, without pseudostroma, but occasionally with paler, lesser corticate areas around the ostioles. Wall carbonized all around, $\leq c .70 \mu \mathrm{m}$ thick. Ostioles eccentric, fused, flat, brown. Hamathecium densely inspersed with hyaline oil globules. Asci with 8 ascospores. Ascospores hyaline, densely muriform with many locules in straight rows and partly skewed septa, broadly ellipsoid, 50-65 $\times 23-27 \mu \mathrm{m}$, rounded, lumina angular, wall $2 \mu \mathrm{m}$ thick.

Pycnidia pale brown, immature but abundant, near the ostioles.

Chemistry. Thallus surface UV-, thallus medulla K-. TLC: no secondary substances detected.

Ecology and distribution. On Hevea brasiliensis bark in plantation. Known only from Brazil.

Discussion. This species is similar to some Astrothelium species that were described in Campylothelium, in the solitary ascomata with eccentric ostioles, but it differs from all other described species by the combination of ascospore size, number of ascospores in the ascus and hamathecium inspersion. It is most similar to A. leioplacum (Müll. Arg.) Aptroot \& Lücking, which has no hamathecium inspersion and shorter ascospores.

Additional material seen. Venezuela: Amazonas: Alto Orinoco, c. $15 \mathrm{~km} \mathrm{SW}$ of La Esmeralda, W bank of Surumoni, on Goupia glabra, alt. 110 m, 1997, Hafellner E̋ Komposch 909-5-24 (GZU). 


\section{Astrothelium xanthosuperbum Aptroot \& M. Cáceres sp. nov.}

\section{MycoBank No.: MB 815187}

Astrothelium similar to $A$. disjunctum Aptroot \& M. Cáceres, but ascospores muriform, 130-160 × 28-35 $\mu \mathrm{m}$.

Type: Brazil, Rondônia, Sítio Ecológico Buriti on Lago Cujubim NE of Porto Velho, $8^{\circ} 35^{\prime} 17^{\prime \prime}$, $63^{\circ} 40^{\prime} 40^{\prime \prime} \mathrm{W}$, alt. c. $100 \mathrm{~m}$, on tree bark in disturbed rainforest, 18 November 2012, M. E. S. Cáceres \& A. Aptroot 15441 (ISE-holotype; ABL-isotype).

\section{(Fig. 4F)}

Thallus corticate, smooth, shiny, continuous, covering areas $\leq 3 \mathrm{~cm}$ diam., under $0.1 \mathrm{~mm}$ thick, olive-green, surrounded by a dark black prothallus line c. $0.3 \mathrm{~mm}$ wide, inducing gall formation of the host bark in the form of making the bark pieces become slightly concave and thickened along the cracks so that they are almost flaking off.

Ascomata globose, $0.4-0.7 \mathrm{~mm}$ diam., solitary, mostly 2-6 aggregated, immersed in pseudostroma. Pseudostromata black, raised above the thallus, irregular in outline or usually in lines, $\leq 2 \mathrm{~mm}$ wide and $\leq 7 \mathrm{~mm}$ long. Wall black all around, $\leq c .50 \mu \mathrm{m}$ thick. Ostioles apical, not fused, flat, dark brown, often surrounded by a pale brown ring. Hamathecium not inspersed with oil globules. Asci with 8 ascospores. Ascospores hyaline, muriform, ellipsoid, $130-160 \times 28-35 \mu \mathrm{m}$, ends rounded, lumina angular, not surrounded by a gelatinous layer.

Pycnidia young, abundant, in the pseudostroma.

Chemistry. Thallus surface UV+ yellow, thallus medulla $\mathrm{K}-$. TLC: lichexanthone.

Ecology and distribution. On smooth bark of trees in disturbed rainforest. Known only from Brazil.

Discussion. This species looks superficially like $A$. disjunctum (see above), but differs in the large muriform ascospores.

\section{Pseudopyrenula flavoreagens Aptroot \& M. Cáceres sp. nov.}

\section{MycoBank No.: MB 815189}

Pseudopyrenula similar to P. subgregaria Müll. Arg., but with lichexanthone in the thallus.
Type: Brazil, Rondônia, Sítio Ecológico Buriti on Lago Cujubim NE of Porto Velho, $8^{\circ} 35^{\prime} 17^{\prime \prime S}$, $63^{\circ} 40^{\prime} 40^{\prime \prime} \mathrm{W}$, alt. c. $100 \mathrm{~m}$, on tree bark in disturbed rainforest, 18 November 2012, M. E. S. Cáceres E A. Aptroot 15443 (ISE-holotype; ABL-isotype).

Thallus not corticate, dull, continuous, covering areas $\leq 2 \mathrm{~cm}$ diam., whitish grey, surrounded by a black hypothallus line c. $0.2 \mathrm{~mm}$ wide, not inducing gall formation of the host bark.

Ascomata globose, $0.25-0.35 \mathrm{~mm}$ diam., single, emergent from the thallus. Wall carbonized, $\leq c .40 \mu \mathrm{m}$ thick. Ostioles apical, not fused, flat, black. Hamathecium inspersed with yellow oil globules. Asci with 8 ascospores. Ascospores hyaline, 3-septate, fusiform, 21-28 × 6-9 $\mu \mathrm{m}$, ends pointed, lumina diamond-shaped, partly yellow, not surrounded by a gelatinous layer.

Pycnidia not observed.

Chemistry. Thallus UV+ yellow, $\mathrm{KOH}-$. TLC: lichexanthone.

Ecology and distribution. On smooth bark of trees in primary forest, but also in disturbed rainforest. Known from Brazil and Panama.

Discussion. This species differs from $P$. subgregaria by the presence of lichexanthone in the thallus. This new species is widespread.

Additional specimens seen. Brazil: Minas Gerais; Catas Altas, Serra do Caraça, Parque Natural de Caraça, near Tanque Grande, on Araucaria, alt. 1270 m, 1997, Aptroot 41518 (SP, ABL).-Panama: Veragues: Bahia Honda, Cabrera \& Etayo 18518 (ABL, hb. Etayo).

\section{Discussion}

Currently, 55 species of Trypetheliaceae are known from this small area in Rondônia, including 46 species of Astrothelium (out of less than 200 known worldwide). The presence of so many species in such a limited area, in addition to the high numbers of species found in lowland areas of the Guianas, Bolivia, Colombia and Venezuela, suggests that the Amazon basin is the centre of diversity for the family, at least for Astrothelium, which in its revised circumscription is the largest genus of the family. 
The CNPq (Conselho Nacional de Desenvolvimento Científico e Tecnológico) is thanked for a research grant to MESC (Processo 311706/2012-6). The costs of the collecting expeditions to MESC were financed by CNPq (CNPq-Protax Processo 562330/2010-0 and INCT-Herbário Virtual Processo 563342/2010-2). Elton Bill Souza and Allyne Christina Gomes Silva are thanked for logistical support and for organizing the collecting trips. Leo Spier is thanked for performing thin-layer chromatography.

\section{REFERENCES}

Aptroot, A. \& Cáceres, M. E. S. (2013) Pyrenocarpous lichens (except Trypetheliaceae) in Rondônia. Lichenologist 45: 763-785.

Aptroot, A. \& Lücking, R. (2016) A revisionary synopsis of the Trypetheliaceae (Ascomycota: Trypetheliales). Lichenologist 48: 763-982.

Aptroot, A., Nelsen, M. P. \& Parnmen, S. (2013a) Marcelaria, a new genus for the Laurera purpurina group in the Trypetheliaceae (Ascomycota: Dothideomycetes). Glalia 5 (2): 1-15.

Aptroot, A., Sipman, H. J. M. \& Cáceres, M. E. S. (2013b) Twenty-one new species of Pyrenula from South America, with a note on over-mature ascospores. Lichenologist 45: 169-198.

Cáceres, M. E. S., Lima, E. L., Aptroot, A. \& Lücking, R. (2014a) Liquens brasileiros: novas descobertas evidenciam a riqueza no Norte e Nordeste do país. Boletim do Museu de Biologia Mello Leitão 35: 101-119.
Cáceres, M. E. S., Aptroot, A., Parnmen, S. \& Lücking, R. (2014b) Remarkable diversity of the lichen family Graphidaceae in the Amazon rain forest of Rondônia, Brazil. Phytotaxa 189: 87-136.

Cáceres, M. E. S., Ertz, D. \& Aptroot, A. (2014c) New species and interesting records of Arthoniales from the Amazon, Rondônia, Brazil. Lichenologist 46: 573-588.

Colinvaux, P. A., De Oliveira, P. E. \& Bush, M. B. (2000) Amazonian and neotropical plant communities on glacial time-scales: the failure of the aridity and refuge hypotheses. Quaternary Science Reviews 19: 141-169.

Hooghiemstra, H. \& Van der Hammen, T. (1998) Neogene and Quaternary development of the neotropical rain forest: the forest refugia hypothesis, and a literature overview. Earth-Science Reviezus 44: 147-183.

Lücking, R. (2008) Foliicolous lichenized fungi. Flora Neotropica Monograph 103: 1-866.

Nelsen, M. P., Lücking, R., Aptroot, A., Andrew, C. J., Cáceres, M. E. S., Rivas Plata, E., Gueidan, C., da Silva Cañez, L., Knight, A., Ludwig, L. R. et al. (2014) Elucidating phylogenetic relationships and genus-level classification within the fungal family Trypetheliaceae (Dothideomycetes: Ascomycota). Taxon 63: 974-992.

Orange, A., James, P. W. \& White, F. J. (2001) Microchemical Methods for the Identification of Lichens. London: British Lichen Society. 